\title{
Development of Mechanisms Associated With Neurogenic-Mediated Skin Inflammation During the Growth of Rats
}

\author{
MIHOKO OHSHIMA, MIO MIYAKE, MASANORI TAKEDA, TAICHIRO MUTO, NORISHI UEDA, KOMEI ITO, \\ AND TATSUO SAKAMOTO
}

\begin{abstract}
Department of Pediatrics [M.O., M.M., M.T., T.M., N.U., T.S.], Nagoya University Graduate School of Medicine, Nagoya 466-8550, Japan; Department of Allergy [K.I.], Aichi Children's Health and Medical Center, Obu 474-8710, Japan; Hazard Evaluation and Epidemiology Research Group [T.S.], National Institute of Occupational Safety and Health, Kawasaki 214-8585, Japan
\end{abstract}

\begin{abstract}
Neurogenic-mediated inflammation may be associated with several inflammatory skin diseases including atopic dermatitis. However, age-dependent differences in neurogenic-mediated skin responses are not fully understood. We compared skin plasma leakage in rats aged 2 and $8 \mathrm{wk}$, which was induced by topical capsaicin, topical formalin, and intracutaneous substance $\mathrm{P}$, whose effects are mediated via tachykinin NK1 receptors. Evans blue dye extravasation served as an index of the increase in skin vascular permeability. Capsaicin, formalin, and substance $\mathrm{P}$ caused a skin response in a dose-dependent manner in both age groups. However, the skin response was much greater in adults than in pups. In addition, the localization of sensory C-fibers and tachykinin NK1 receptors in the skin was investigated by immunofluorescent staining with antisubstance P and antitachykinin NK1 receptor antibodies, respectively. Substance P-immunoreactive nerves were detected throughout the dermis and tachykinin NK1 receptors were mainly detected in blood vessel walls in the dermis in both age groups. However, they were more sparsely distributed in pups. In conclusion, the weak neurogenic-mediated skin inflammation in pups is probably because of immature neural mechanisms associated with skin inflammation such as reduced innervation of sensory C-fibers and low expression of tachykinin NK1 receptors. (Pediatr Res 67: 363-368, 2010)
\end{abstract}

$\mathrm{N}^{\mathrm{e}}$ urogenic-mediated inflammation may be associated with several inflammatory skin diseases including atopic dermatitis (1). Immediately after stimulation of nerve endings of sensory $\mathrm{C}$-fibers, antidromic conduction through afferent nerve collaterals causes the release of neuropeptides such as substance $\mathrm{P}$ and calcitonin gene-related peptide from nerve endings of sensory $\mathrm{C}$-fibers. The released neuropeptides lead to pain, pruritus, vascular modulation (i.e. plasma leakage, vasodilation, and endothelial cell activation), and activation of immune cells including T- and B-cells, and mast cells (1-3).

In animal experimental models, it is more difficult to elicit neurogenic-mediated skin inflammation in younger animals, particularly during the perinatal period. Fitzgerald and Gibson (4) showed that topical mustard oil and antidromic stimulation of the sciatic nerve of rats, which specifically stimulate sen-

Received April 30, 2009; accepted November 25, 2009.

Correspondence: Tatsuo Sakamoto, M.D., Ph.D., Hazard Evaluation and Epidemiology Research Group, National Institute of Occupational Safety and Health, Nagao 6-21-1, Tama-ku, Kawasaki 214-8585, Japan; e-mail: sakamoto@h.jniosh.go.jp

Supported by Nagoya University Graduate School of Medicine. sory $\mathrm{C}$-fibers in the skin, are incapable of producing plasma leakage in the paw until postnatal day 11 . However, this is inconsistent with previous data that substance P-immunoreactive nerves are detected even in the skin of rats aged day $0-1$ $(4,5)$. Schotzinger and Landis (5) reported increases in the number of substance P-immunoreactive nerves in rat skin, branching pattern of nerves, and substance $\mathrm{P}$ immunoreactivity throughout neonatal life that approach adult levels by postnatal day 21. Therefore, the histologic immaturity of sensory C-fibers may be one reason for the lack or reduced level of neurogenic-mediated skin inflammation in rat pups. Neurogenic-mediated skin inflammation is also likely to depend on the expression of tachykinin NK1 receptors. Gonzales et al. (6) reported that intracutaneous substance $\mathrm{P}$ does not induce skin plasma leakage until postnatal day 13 and that the magnitude of the skin response increases with age, which reflects the lack of expression or activity of tachykinin NK1 receptors until postnatal day 13 . Mechanisms underlying such age-dependent neurogenic-mediated skin inflammation are not fully understood.

To confirm whether neurogenic-mediated skin plasma leakage increases with age, we investigated plasma leakage in rat skin induced by topical capsaicin and formalin using two age groups of rats aged 2 and $8 \mathrm{wk}$. This leakage is mediated via tachykinin NK1 receptors that are stimulated by endogenously released tachykinins (7-9) and is similar to that induced by topical mustard oil $(10,11)$. The skin response induced by intracutaneous substance $\mathrm{P}$ was also examined to analyze the functional development of tachykinin NK1 receptors. Neurogenic-mediated skin plasma leakage appears to depend on several neural mechanisms such as innervation of sensory C-fibers, releasability of neuropeptides from sensory C-fibers, distribution, and activity of tachykinin NK1 receptors, and activity of neuropeptide degrading enzymes such as neutral endopeptidases $(1,3)$. In this study, we investigated agerelated differences in the localization of sensory C-fibers and tachykinin NK1 receptors, and the releasability of substance $\mathrm{P}$ from sensory C-fibers in response to capsaicin by immunohistochemical analysis. In addition, the effect of phosphoram-

Abbreviation: TRPV1, Transient receptor potential vanilloid 1 
idon, a neutral endopeptidase 24.11 inhibitor $(12,13)$, on skin plasma leakage induced by substance $\mathrm{P}$ was studied to evaluate the activity of neutral endopeptidase in the skin.

\section{MATERIALS AND METHODS}

Animals. All animal experimentation was conducted with the prior approval of the Animal Ethics Committee of the Institute for Laboratory Animal Research, Nagoya University Graduate School of Medicine. This committee has established a program for activities involving animals in accordance with the Guide for the Care and Use of Laboratory Animals of Nagoya University (2007; Nagoya, Japan). Pathogen-free male Wistar rats aged 13 d (20-22 g) and 8 wk (240-260 g) were purchased from Japan SLC, Inc., (Hamamatsu, Japan) $3 \mathrm{~d}$ before the experiment. All rats were housed in a temperaturecontrolled room and given free access to food and water. Rat pups that had not been weaned were housed with dams in polycarbonate cages with polyester filter covers.

Reagents. Capsaicin was purchased from Calbiochem (La Jolla, CA). Formaldehyde solution containing 13\% methanol (formalin), substance P, ethanol, diethyl ether, Evans blue dye, formamide, PBS, and urethane were from Sigma Chemical Co. Aldrich Japan (Tokyo, Japan). Phosphoramidon was from the Peptide Institute (Osaka, Japan), and 0.9\% saline was from Otsuka Chemical (Tokyo, Japan). Capsaicin, formalin, and substance P were dissolved in neat ethanol, distilled water containing $13 \%$ methanol, and $0.9 \%$ saline, respectively. Evans blue dye and phosphoramidon were dissolved in $0.9 \%$ saline.

Skin administration of capsaicin, formalin, and substance $P$. All rats were anesthetized with gaseous diethyl ether $1 \mathrm{~d}$ after closely shaving the skin of the abdomen. On the shaved abdomen of rats aged $16 \mathrm{~d}, 6 \mu \mathrm{L}$ of various concentrations of capsaicin, formalin, or vehicle was randomly placed on 10-mm diameter circular exposure sites (4 sites/animal), which immediately spread over the area of the circle within $5 \mathrm{~s}$. Rats aged $8 \mathrm{wk}$ were administered $12 \mu \mathrm{L}$ of each of the chemicals on the areas of circles of $14 \mathrm{~mm}$ in diameter. Skin samples were collected $40 \mathrm{~min}$ after topical application. Various concentrations of substance $\mathrm{P}$ or vehicle were injected intracutaneously, on the shaved abdomen of 2- and 8-wk-old rats, using 20 and $50 \mu \mathrm{L} / \mathrm{site}$, respectively, and skin samples were harvested 20 min later.

Measurement of skin microvascular leakage. Evans blue dye solution (20 $\mathrm{mg} / \mathrm{kg})$ was administered to anesthetized rats aged $2(0.5 \mathrm{~mL} /$ animal $)$ and 8 wk ( $1 \mathrm{~mL} /$ animal) via the caudal vein over a period of $1 \mathrm{~min}$, followed $1 \mathrm{~min}$ later by skin administration of the chemicals. Animals were killed by an overdose of urethane ( $>4 \mathrm{~g} / \mathrm{kg}$ i.p.). The thoracic cavity was opened, followed by the insertion of a cannula into the aorta through the left ventricle. Perfusion was performed using $0.9 \%$ saline. Skin samples were punched out, and the dye that had leaked into the skin was extracted in $2 \mathrm{~mL}$ of formamide at $37^{\circ} \mathrm{C}$ for $72 \mathrm{~h}$. The amount of dye in the supernatant was measured using a spectrophotometer (Model 450; Bio-Rad Laboratories, Hercules, CA) at a wavelength of $620 \mathrm{~nm}$. The tissue content of the dye was calculated by interpolation using a standard curve of dye concentration within a range of $0.3-30 \mu \mathrm{g} / \mathrm{mL}$.

Assessment of neutral endopeptidase activity. Rats were pretreated with phosphoramidon $(2.5 \mathrm{mg} / \mathrm{kg}$ i.v.) or vehicle and then intracutaneously injected with substance $\mathrm{P}$ as described above. The dose of phosphoramidon used enhances plasma extravasation in the skin and scratching behavior induced by intracutaneous poly-L-arginine in rats (14).

Immunohistochemistry. Skin samples were stored in 10\% phosphatebuffered formalin. Paraffin-embedded sections (4- $\mu \mathrm{m}$ thick) were deparaffinized, microwave-heated $(500 \mathrm{~W}, 5 \mathrm{~min})$ in citrate buffer $(\mathrm{pH} 6.0)$, and incubated in PBS containing $1.5 \%$ normal goat serum (Vector Laboratories, Burlingame, CA) to block unoccupied sites for staining of substance P, tachykinin NK1 receptors, and endothelial cells. Mouse serum (Vector Laboratories) was also used as a blocking agent for the detection of transient receptor potential vanilloid (TRPV) 1 . The sections were then incubated with a primary antibody (1:100) for $30 \mathrm{~min}$, followed by a secondary antibody (1:100) for $30 \mathrm{~min}$. Rabbit antisera to substance P (Chemicon International, Temecula, CA), goat IgG polyclonal antibody to TRPV1 (Santa Cruz Biotechnology, Santa Cruz, CA), rabbit IgG polyclonal antibody to tachykinin NK1 receptors (Sigma Chemical Co. Aldrich Japan), and mouse IgG1 MAb to rat endothelial cells (Hycult biotechnology, Uden, Netherlands) were used as primary antibodies. A goat $\operatorname{IgG}$ polyclonal antibody to rabbit IgG (Jackson ImmunoResearch Laboratories, West Grove, PA), mouse IgG polyclonal antibody to goat IgG (Chemicon International) and goat IgG polyclonal antibody to mouse IgG1 (Invitrogen, Carlsbad, CA), which were conjugated with $\mathrm{Cy} 3$, were used as secondary antibodies for indirect immunofluorescent staining. The sections were washed with PBS and distilled water before each step. Nonimmune goat IgG (Chemicon International) and nonimmune rabbit serum (Pierce Biotechnology, Rockford, IL) were used as negative controls for the primary antibody. Finally, the sections were counterstained with Gill's hematoxylin stain (Falma, Tokyo, Japan) for $5 \mathrm{~s}$, dehydrated through ascending ethanol concentrations, cleared with Clear Plus (Falma), and cover slipped with a mounting medium (Supermount; Falma). Sections were examined using an Axiovert S100 microscope (Carl Zeiss, Thornwood, NY), equipped with an AxioCam MRm camera (Carl Zeiss). The computer software, AxioVision 4.2 (Carl Zeiss), was used for image processing and analysis.

Measurements of the length of substance P-and TRPV1-immunoreactive nerve fibers in the dermis. Photographs of 10 random fields $\left(0.32 \mathrm{~mm}^{2}\right.$, $\times 400$ magnification) were taken of different sections of each of the skin samples using an Axiovert S100 microscope equipped with an AxioCam MRm camera. The length of fragment of substance P- and TRPV1immunoreactive nerves, and the area of the dermis visible within these sections were measured using AxioVision 4.2. All values are expressed as the length of the fragments of substance P- and TRPV1-immunoreactive nerves per $1 \mathrm{~mm}^{2}$ of total area of the dermis. All analyses were performed twice in a blinded manner. No significant differences were noted between the two sets of results.

Determination of the number of degranulating dermal mast cells. Formalin-fixed, paraffin-embedded sections (4- $\mu \mathrm{m}$ thick) of the skin were stained with toluidine blue, which is a reliable and widely used marker for mast cells (Muto Pure Chemicals, Tokyo, Japan). The total number of dermal mast cells in 15 random fields $\left(2.4 \mathrm{~mm}^{2}\right)$ from different sections of each of the skin samples was determined using light microscopy at a magnification of $\times 400$. Degranulating mast cells were histomorphologically distinguished from intact nondegranulating cells as previously described $(>10 \%$ of the cytoplasmic granules exhibiting fusion, stain alterations, or extrusion from the cells; Refs. 15,16).

Measurement of substance P content in the skin. The amount of substance $\mathrm{P}$ in the skin of the abdomen was analyzed according to the method described by Onishi et al. (17) with minor modifications. Briefly, skin samples were cut into $0.1-\mathrm{g}$ specimens, rinsed in PBS, and vigorously homogenized using a BM-2-homogenizer (Nihonseiki, Nagaoka, Japan) in $1 \mathrm{~mL}$ of a reagent for tissue lysis and extraction (CelLytic MT; Sigma Chemical Co. Aldrich Japan) containing a protease inhibitor cocktail (Complete; Sigma Chemical Co. Aldrich Japan). After 90-min incubation at room temperature, the homogenate was centrifuged at $15,000 \times g$ at $4^{\circ} \mathrm{C}$ for $15 \mathrm{~min}$. The amount of substance $\mathrm{P}$ in the supernatant was determined using a commercially available competitive ELISA kit for substance P (Cayman Chemical, Ann Arbor, MI).

Statistical analysis. Results are expressed as the mean \pm SEM. To evaluate the significance of differences between two independent groups with equal variance, which were originally assessed using the $\mathrm{F}$ test, we performed an unpaired $t$ test (two tailed). When the variance was unequal, we used Welch's test (two tailed). For multiple comparisons with the control, the Dunnett's test was applied if one-way analysis of variance yielded a significant difference. A level of $p<0.05$ was considered to be statistically significant.

\section{RESULTS}

Skin plasma extravasation induced by topical capsaicin and formalin, and intracutaneous substance $P$. Topical capsaicin, topical formalin, and intracutaneous substance P significantly increased the amount of Evans blue dye extravasated into the skin of 2- and 8-wk-old rats in a dose-dependent manner (Figs. 1 and 2). Application of vehicle alone had no effect on the amount of dye extravasated. The skin response induced by capsaicin, formalin, and substance P largely increased with age. Their threshold concentrations for inducing the skin response were lower in adults than in pups. Phosphoramidon increased the skin microvascular leakage induced by substance P (pups: $6 \mu \mathrm{M}$; adults: $0.6 \mu \mathrm{M}$ ) by $20.7 \%(p>$ $0.1)$ and $47.2 \%(p<0.01)$ in pups and adults, respectively.

Immunohistochemical localization of sensory C-fibers and tachykinin NK1 receptors. The skin and dermis were both thinner in pups than in adults as assessed by hematoxylin and eosin staining of skin sections (Fig. 3). Blood vessels, 


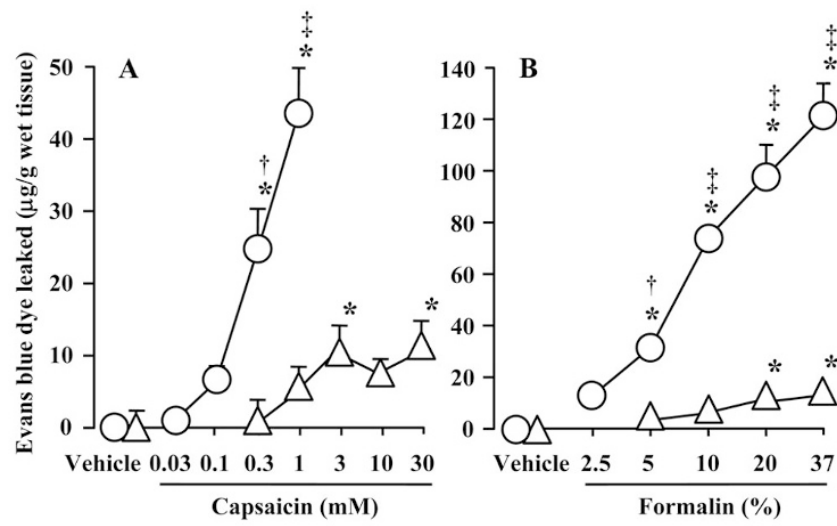

Figure 1. Age-related differences in skin plasma leakage induced by topical capsaicin and formalin. The indicated concentrations of capsaicin $(A)$, formalin $(B)$, and vehicle control, were applied to rats aged $2(\triangle)$ and $8(\bigcirc)$ wk. The Evans blue dye content in the skin was measured as an index of increased vascular permeability. Values are expressed as the mean \pm SEM $(n=6)$. $* p<0.05$ vs vehicle, assessed by Dunnett's test; $\uparrow p<0.05, \ddagger p<0.01$ comparison of two different age groups, assessed by an unpaired $t$ test or by Welch's test.

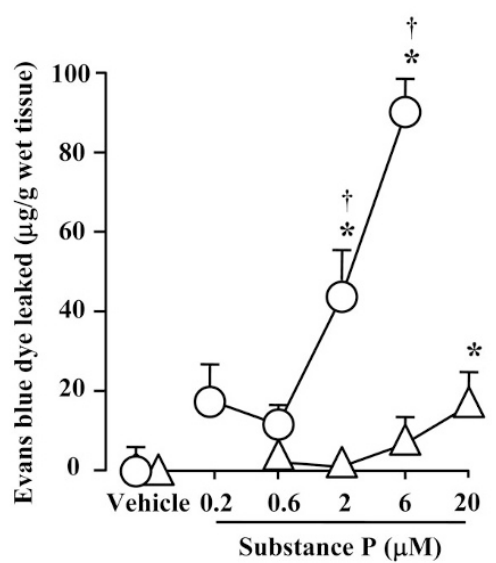

Figure 2. Age-related differences in skin plasma leakage induced by intracutaneous substance $P$. The indicated concentration of intracutaneous substance $\mathrm{P}$ or vehicle was applied to rats aged $2(\triangle)$ and $8(\bigcirc)$ wk. The Evans blue dye content in the skin was measured as an index of increased vascular permeability. Values are expressed as the mean $\pm \operatorname{SEM}(n=6) .{ }^{*} p<0.05$ vs vehicle, assessed by Dunnett's test; $\dagger p<0.01$ comparison of rat pups and adults, assessed by an unpaired $t$ test or by Welch's test.

detected by immunofluorostaining using an anti-rat endothelial cell antibody, were more sparsely distributed in the dermis of rat pups than in adults (Fig. 3). Substance P- and TRPV1immunoreactive nerves were distributed throughout the dermis in both age groups (Fig. 4). However, in pups, the length of substance P- and TRPV1-immunoreactive fibers within a given area was lower, suggesting that their branching was less developed. The length of substance P-immunoreactive nerves was $2.38 \pm 0.35 \mathrm{~mm} / \mathrm{mm}^{2}$ in pups and $3.70 \pm 0.22 \mathrm{~mm} / \mathrm{mm}^{2}$ in adults $(n=6$ for each group, $p<0.05)$. The length of TRPV1-immunoreactive nerves was $2.13 \pm 0.23 \mathrm{~mm} / \mathrm{mm}^{2}$ in pups and $3.20 \pm 0.31 \mathrm{~mm} / \mathrm{mm}^{2}$ in adults $(n=6$ for each group, $p<0.05$ ). Tachykinin NK1 receptors were detected by immunofluorescent staining mainly on endothelial cells of blood vessels in the dermis in the two age groups, although

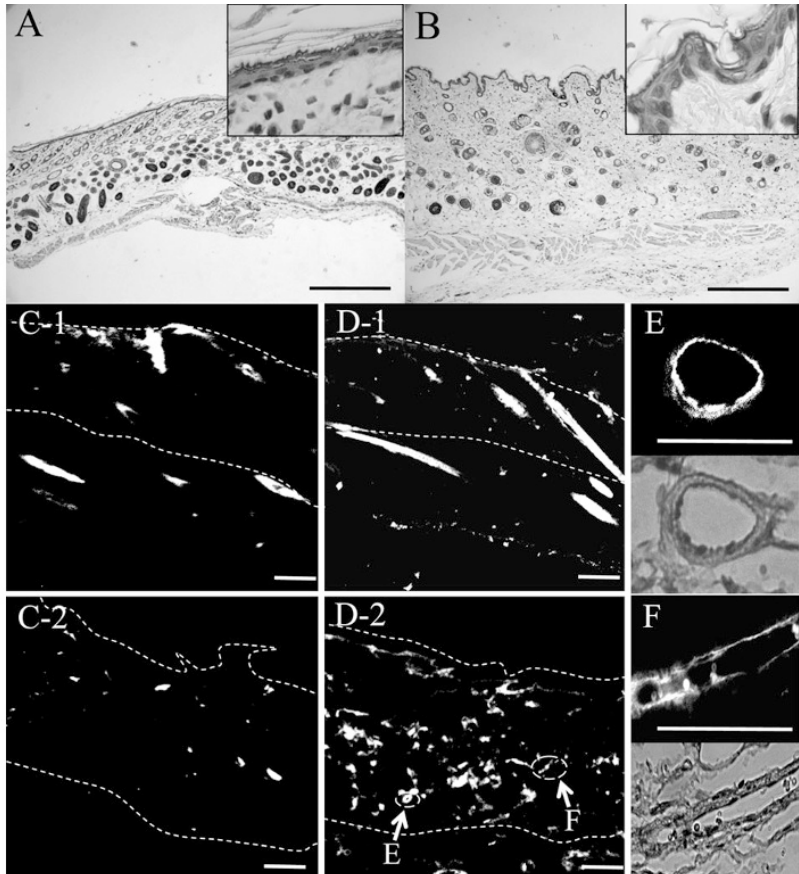

Figure 3. Histologic features of the skin of rats of different ages. Formalinfixed, paraffin-embedded skin sections of rats aged $2(A)$ and $8(B)$ wk were stained with hematoxylin and eosin, and assessed by light microscopy at $\times 400$ magnification. Bars $=500 \mu \mathrm{m}$. Immunohistochemical localization of endothelial cells in the abdominal skin of rats aged $2(C-2)$ and $8(D-2)$ wk was examined using an anti-rat endothelial cell antibody. Nonspecific mouse IgG1 was used as a primary antibody for negative controls $(C-1$ and $D-1$, respectively). Endothelial cells were mainly localized throughout the dermis in both age groups. Hair follicles were nonspecifically detected in the two age groups. The dotted lines show the upper and lower borders of the dermis. The arrows in D-2 indicate transverse $(E)$ and longitudinal $(F)$ sections of blood vessels. The lower panels of $E$ and $F$ were counterstained with Gill's Hematoxylin. Bars $=100 \mu \mathrm{m}$. The photographs are representative of at least six independent experiments in which identical results were obtained.
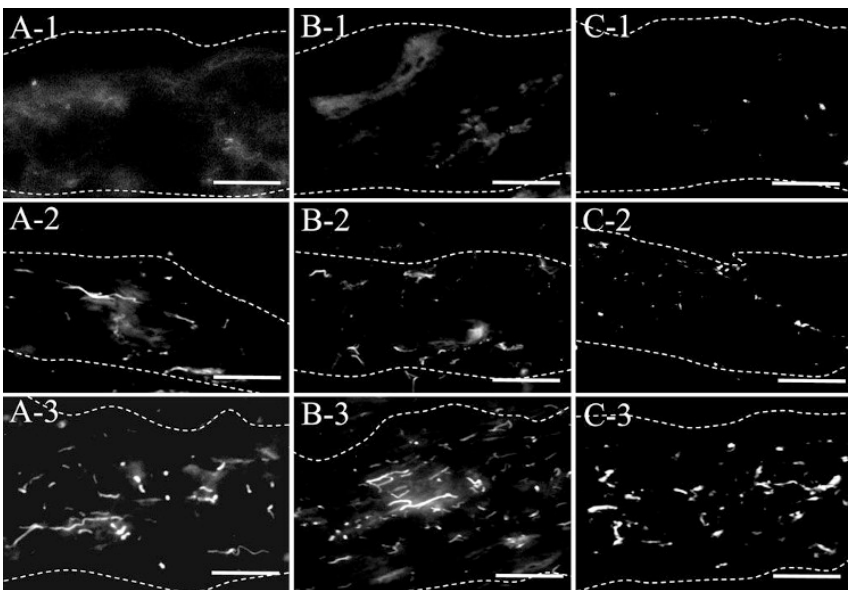

Figure 4. Immunofluorescent staining of substance P- and TRPV 1-immunoreactive nerves and tachykinin NK1 receptors in rats of different ages. Samples of the abdominal skin of rats aged $2(A-2, B-2$, and $C-2)$ and $8(A-3$, $B-3$, and $C-3)$ wk were analyzed by immunofluorescence for the presence of sensory $\mathrm{C}$-fibers using antisubstance $\mathrm{P}$ (left panels) and anti-TRPV1 (middle panels) antibodies and, for tachykinin NK1 receptors (right panels), using a specific antibody. Nonspecific rabbit serum or goat $\operatorname{IgG}$ was used as a primary antibody for negative controls $(A-1, B-1$, and $C-1)$. The dotted lines indicate the upper and lower borders of the dermis. Bars $=100 \mu \mathrm{m}$. The photographs are representative of at least six independent experiments in which identical results were obtained. 

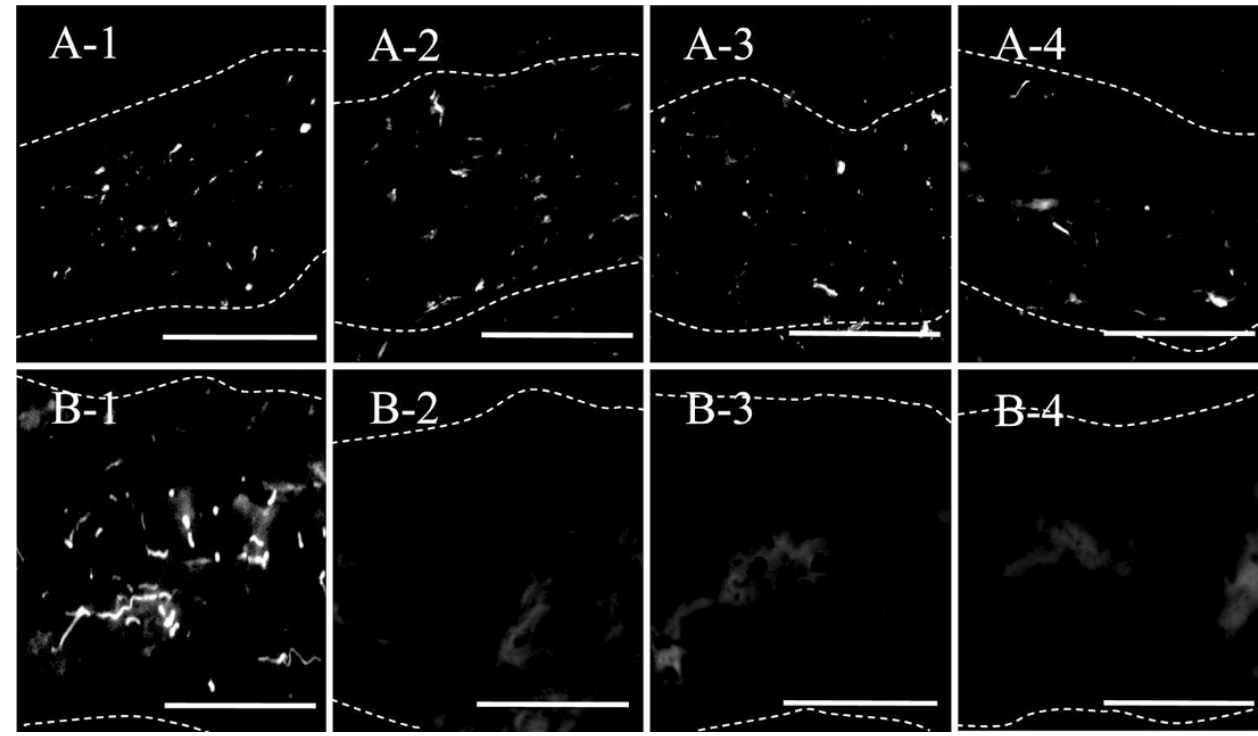

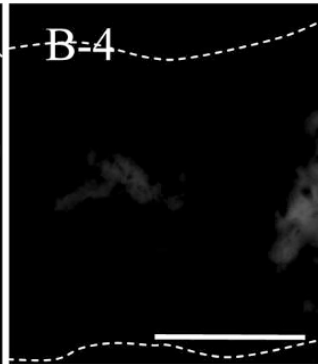

Figure 5. Releasability of substance $P$ from sensory C-fibers in the skin of the abdomen of rats of different ages. Skin samples were collected from 2- $(A, 1-4)$ and 8 -wk-old $(B, 1-4)$ rats $90 \mathrm{~min}$ after topical application of capsaicin $(0.3 \mathrm{mM}$ : $A-2$ and $B-2 ; 1 \mathrm{mM}$ : $A-3$ and $B-3 ; 10 \mathrm{mM}$ : $A-4$ and $B-4)$ or vehicle $(A-1$ and $B-1)$. Samples were stained with an antisubstance $\mathrm{P}$ antibody to assess the immunofluorescent intensity of substance $\mathrm{P}$ in the skin. The dotted lines indicate the upper and lower borders of the dermis. Bars = $100 \mu \mathrm{m}$. The photographs are representative of six independent experiments in which identical results were obtained. they were more densely distributed in the adults than in the pups (Fig. 4).

Pretreatment with topical capsaicin $(0.3,1$, and $10 \mathrm{mM})$ slightly decreased the length of substance P-immunoreactive nerves within a given area in the dermis of pups (Fig. 5A, 1-4). Capsaicin (10 mM) slightly decreased the length of substance P-immunoreactive nerves from $2.23 \pm 0.28$ to $1.77 \pm 0.27 \mathrm{~mm} / \mathrm{mm}^{2}(n=6, p>0.1)$. In contrast, even as low a concentration as $0.3 \mathrm{mM}$ of capsaicin almost completely eliminated substance P-immunoreactive nerves in adults (Fig. $5 B, 1-4)$.

Content of substance $P$ in the skin. The content of substance $\mathrm{P}$ in the skin was significantly different $(p<0.01)$ between 2 - and 8 -wk-old rats being $45.0 \pm 1.4(n=6)$ and $51.0 \pm 1.1 \mathrm{ng} / \mathrm{g}$ of wet tissue $(n=6)$, respectively.

Mast cell degranulation induced by topical capsaicin. The total number of dermal mast cells was also significantly different $(p<0.01)$ between 2 - and 8-wk-old rats, being $91.35 \pm 7.14(n=6)$ and $34.61 \pm 1.48$ cells $/ \mathrm{mm}^{2}(n=6)$, respectively. When treated with vehicle, the percentage of degranulating dermal mast cells in the two age groups was similar. Topical capsaicin at a concentration of 1 or $10 \mathrm{mM}$ significantly increased the proportion of degranulating dermal mast cells in adults (Fig. 6). However, topical capsaicin had no effect on the proportion of degranulating mast cells in pups.

\section{DISCUSSION}

In this study, by using immunohistochemical methods, we found that the total length of substance P- and TRPV1immunoreactive nerves per field, which mainly represent sensory C-nerves $(5,18)$, was greater in adults than in pups. However, substance $\mathrm{P}$ content in the skin, as measured by ELISA, was only $13 \%$ higher in adults than in pups, although there was a significant difference between those of the two age groups. The substance $\mathrm{P}$ content includes not only that of the dermis but also that in other skin areas, which may provide one explanation of the discrepancy between these data. Schotzinger and Landis (5) showed that the number and

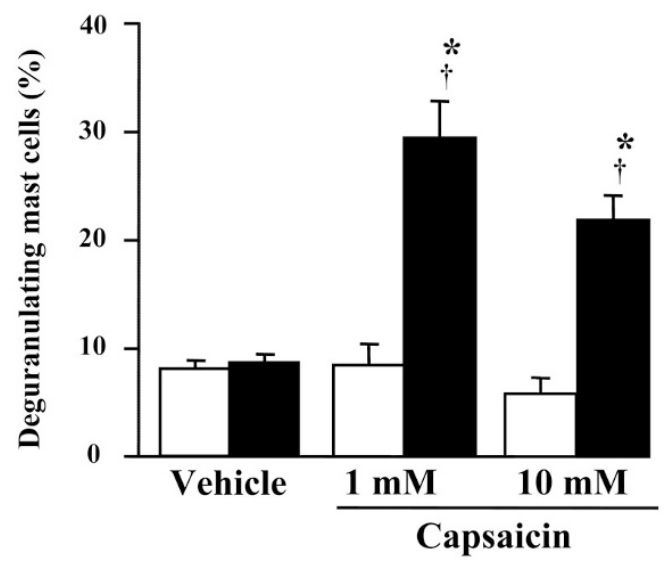

Figure 6. Effect of topical application of capsaicin on degranulation of dermal mast cells in rats of different ages. Capsaicin (1 and $10 \mathrm{mM})$ or vehicle was topically applied to the skin of 2- $(\square)$ and 8-wk-old ( $\square$ ) rats, and the percentage of degranulating dermal mast cells per $1 \mathrm{~mm}^{2}$ of total area was calculated. Under light microscopy ( $\times 400$ magnification), the total number of dermal mast cells was counted in skin sections stained with toluidine blue, and degranulating dermal mast cells were histomorphologically distinguished from intact nondegranulating cells. Values represent the mean \pm SEM $(n=6) . * p<0.01 v s$ pups assessed using an unpaired $t$ test or by Welch's test. $\dagger p<0.05$ vs vehicle, assessed by Dunnett's test.

immunofluorescence intensity of substance P-immunoreactive nerves in rat skin increase with age and reach adult levels by postnatal day 21. Their finding of a difference in the distribution of sensory C-fibers on postnatal days 14 and 21 (5) is similar to our data using rats aged $16 \mathrm{~d}$ and $8 \mathrm{wk}$. Tachykinin NK1 receptors were detected mainly on endothelial cells of blood vessels in the dermis in both adults and pups, and these receptors were more widely distributed in adults than in pups. Because using immunofluorescent staining of endothelial cells showed that the dermis of adults was more densely populated by blood vessels than that of pups, this age-related difference in the distribution of tachykinin NK1 receptors may reflect the developmental increase in blood vessels in the dermis. To our knowledge, postnatal development of tachykinin NK1 receptors in the skin has not been elucidated, although Vandevska- 
Radunovic et al. (19) demonstrated that tachykinin NK1 receptors in developing rat dental tissues were spare on postnatal day 7 and thereafter their numbers increased up to postnatal day 21 .

Topical capsaicin induces the release of tachykinins from sensory C-fibers $(7,9)$. Therefore, the immunofluorescent intensity of substance $\mathrm{P}$ in the skin should decrease or disappear after topical application of capsaicin. We found that topical capsaicin strongly decreased the substance P-immunoreactivity of adults but not of pups. These results suggest that the releasability of substance $\mathrm{P}$ from sensory $\mathrm{C}$-fibers may be much lower in pups than in adults.

We showed that topical capsaicin and formalin caused skin microvascular leakage in a dose-dependent manner in both rat pups and adults and that the magnitude of the skin response was much less and its threshold was higher in pups than in adults. Fitzgerald and Gibson (4) showed that topical mustard oil induces skin plasma leakage after postnatal day 11 in rats and that the skin response increases with age. Both studies provide evidence that the neurogenic-mediated skin response is age dependent. Mustard oil has been shown to specifically stimulate sensory $\mathrm{C}$-fibers via the transient receptor potential (TRP) A1 but not via TRPV1 (20). On the other hand, capsaicin activates sensory $\mathrm{C}$-fibers via TRPV1 but not via TRPA1 (18). Like mustard oil, formalin induces the neurogenic-mediated skin response via TRPA1 receptors but not via TRPV1 (21,22). The combined findings suggest that skin plasma leakage induced by stimulation of TRPV1 or TRPA1 may be much lower in pups than in adults, which might make it more difficult to produce the skin response in pups than in adults. Fitzgerald and Gibson (4) also showed that the extent of the skin response that occurred during the period of 15-18 $\mathrm{d}$ after birth was only half that observed extent in adults, although such age-related difference was much greater in our study. The reasons for the discrepancy between these two studies are unclear. One possible reason is that capsaicin and formalin were topically applied on the skin of the abdomen in this study, while mustard oil was applied on the skin of the hind paw in the other study.

Our results demonstrated that skin microvascular leakage induced by intracutaneous substance $\mathrm{P}$ was much lower in pups than in adults. Gonzales et al. (6) also showed that the skin response induced by intracutaneous substance $\mathrm{P}$ is detectable from postnatal day 13 and that it increases with age. However, the skin response was much less on postnatal day 16 than in adults as shown in our study. Our results also show that tachykinin NK1 receptors and endothelial cells were sparsely located in the dermis of pups compared with adults, which may contribute to the great age-related difference that we demonstrated. In addition, the functional development of tachykinin NK1 receptors in the skin of pups may be involved, although this was not assessed.

Neutral endopeptidase is expressed in vascular endothelial cells, fibroblasts, keratinocytes, and skin appendages (23). Neutral endopeptidase modulates neurogenic inflammation by degrading tachykinins (24), and transient inhibition of neutral endopeptidase by phosphoramidon amplifies neurogenicmediated skin vascular permeability (13). We showed that phosphoramidon significantly enhanced plasma leakage in the skin induced by intracutaneous substance $\mathrm{P}$ in adult rats but not in pups, suggesting that the activity of neutral endopeptidase in the skin may increase with age. This result is consistent with the previous in vitro study of Kletsas et al. (25), in which neutral endopeptidase activity in human skin fibroblast cell lines increased during the fetal-to-adult transition.

Topical capsaicin induces dermal mast cell degranulation in adults mainly via tachykinin release from sensory $\mathrm{C}$-fibers $(9,16,26)$. However, in this study, capsaicin had no such effect in pups, although the number of dermal mast cells per $1 \mathrm{~mm}^{2}$ of skin was higher in pups than in adults. The age-dependent difference in mast cell degranulation may be closely associated with the age difference in releasability of tachykinins from sensory $\mathrm{C}$-fibers. The secondary release of histamine and serotonin from mast cells causes plasma leakage in the skin $(9,16,26)$. Therefore, the age-dependent difference in neurogenic-mediated skin plasma leakage may be partly because of the age-related difference in mast cell degranulation via a neurogenic-mediated pathway.

In conclusion, sensorineural stimulation by topical capsaicin, topical formalin, and intracutaneous substance $\mathrm{P}$ produced skin plasma leakage in a dose-dependent manner, and this response increased with age in rats. Several neural components, including the length of sensory C-fibers within a given area, the releasability of substance $\mathrm{P}$ from sensory C-fibers in response to capsaicin, and the local expression of tachykinin NK1 receptors, were immature even in rats aged $16 \mathrm{~d}$ compared with adults. In addition, although more mast cells were detected in the skin of pups, these cells were almost insensitive to capsaicin. The age-related difference in neurogenic-mediated skin plasma leakage may be because of such immaturity.

\section{REFERENCES}

1. Cevikbas F, Steinhoff A, Homey B, Steinhoff M 2007 Neuroimmune interactions in allergic skin diseases. Curr Opin Allergy Clin Immunol 7:365-373

2. Holzer P 1998 Neurogenic vasodilatation and plasma leakage in the skin. Gen Pharmacol 30:5-11

3. Roosterman D, Goerge T, Schneider SW, Bunnett NW, Steinhoff M 2006 Neuronal control of skin function: the skin as a neuroimmunoendocrine organ. Physiol Rev 86:1309-1379

4. Fitzgerald M, Gibson S 1984 The postnatal physiological and neurochemical development of peripheral sensory C fibres. Neuroscience 13:933-944

5. Schotzinger RJ, Landis SC 1990 Postnatal development of autonomic and sensory innervation of thoracic hairy skin in the rat. A histochemical, immunocytochemical, and radioenzymatic study. Cell Tissue Res 260:575-587

6. Gonzales R, Coderre TJ, Sherbourne CD, Levine JD 1991 Postnatal development of neurogenic inflammation in the rat. Neurosci Lett 127:25-27

7. Moussaoui SM, Montier F, Carruette A, Blanchard JC, Laduron PM, Garret C 1993 A non-peptide NK1-receptor antagonist, RP 67580, inhibits neurogenic inflammation postsynaptically. Br J Pharmacol 109:259-264

8. Damas J, Liegeois JF 1999 The inflammatory reaction induced by formalin in the rat paw. Naunyn Schmiedebergs Arch Pharmacol 359:220-227

9. Futamura M, Goto S, Kimura R, Kimoto I, Miyake M, Ito K, Sakamoto T 2009 Differential effects of topically applied formalin and aromatic compounds on neurogenic-mediated microvascular leakage in rat skin. Toxicology 255:100-106

10. Lembeck F, Donnerer J, Tsuchiya M, Nagahisa A 1992 The non-peptide tachykinin antagonist, CP-96,345, is a potent inhibitor of neurogenic inflammation. Br J Pharmacol 105:527-530

11. Inoue H, Asaka T, Nagata N, Koshihara Y 1997 Mechanism of mustard oil-induced skin inflammation in mice. Eur J Pharmacol 333:231-240

12. Matsas R, Fulcher IS, Kenny AJ, Turner AJ 1983 Substance $P$ and [Leu]enkephalin are hydrolyzed by an enzyme in pig caudate synaptic membranes that is identical with the endopeptidase of kidney microvilli. Proc Natl Acad Sci USA 80:3111-3115

13. Iwamoto I, Ueki IF, Borson DB, Nadel JA 1989 Neutral endopeptidase modulates tachykinin-induced increase in vascular permeability in guinea pig skin. Int Arch Allergy Appl Immunol 88:288-293 
14. Hayashi K, Sato H, Kaise T, Ohmori K, Ishii A, Sano J, Karasawa A 2001 Roles of mast cells and sensory nerves in cutaneous vascular hyperpermeability and scratching behavior induced by poly-L-arginine in rats. Eur J Pharmacol 425:219-227

15. Wershil BK, Murakami T, Galli SJ 1988 Mast cell-dependent amplification of an immunologically nonspecific inflammatory response. Mast cells are required for the full expression of cutaneous acute inflammation induced by phorbol 12-myristate 13-acetate. J Immunol 140:2356-2360

16. Siebenhaar F, Magerl M, Peters EM, Hendrix S, Metz M, Maurer M 2008 Mas cell-driven skin inflammation is impaired in the absence of sensory nerves. J Allergy Clin Immunol 121:955-961

17. Onishi N, Kawamoto S, Suzuki H, Santo H, Aki T, Shigeta S, Hashimoto K, Hide M, Ono K 2007 Dietary pulverized konjac glucomannan suppresses scratching behavior and skin inflammatory immune responses in NC/Nga mice. Int Arch Allergy Immunol 144:95-104

18. Caterina MJ, Schumacher MA, Tominaga M, Rosen TA, Levine JD, Julius D 1997 The capsaicin receptor: a heat-activated ion channel in the pain pathway. Nature 389:816-824

19. Vandevska-Radunovic V, Fristad I, Wimalawansa SJ, Kvinnsland IH 2003 CGRP1 and NK1 receptors in postnatal, developing rat dental tissues. Eur J Oral Sci 111:497-502
20. Bautista DM, Jordt SE, Nikai T, Tsuruda PR, Read AJ, Poblete J, Yamoah EN, Basbaum AI, Julius D 2006 TRPA1 mediates the inflammatory actions of environmental irritants and proalgesic agents. Cell 124:1269-1282

21. Bolcskei K, Helyes Z, Szabo A, Sandor K, Elekes K, Nemeth J, Almasi R, Pinter E, Petho G, Szolcsanyi J 2005 Investigation of the role of TRPV1 receptors in acute and chronic nociceptive processes using gene-deficient mice. Pain 117:368-376

22. McNamara CR, Mandel-Brehm J, Bautista DM, Siemens J, Deranian KL, Zhao M, Hayward NJ, Chong JA, Julius D, Moran MM, Fanger CM 2007 TRPA1 mediates formalin-induced pain. Proc Natl Acad Sci USA 104:13525-13530

23. Scholzen TE, Luger TA 2004 Neutral endopeptidase and angiotensin-converting enzyme-key enzymes terminating the action of neuroendocrine mediators. Exp Dermatol 13:22-26

24. Rubinstein I, Iwamoto I, Ueki IF, Borson DB, Nadel JA 1990 Recombinant neutra endopeptidase attenuates substance P-induced plasma extravasation in the guinea pig skin. Int Arch Allergy Appl Immunol 91:232-238

25. Kletsas D, Caselgrandi E, Barbieri D, Stathakos D, Franceschi C, Ottaviani E 1998 Neutral endopeptidase-24.11 (NEP) activity in human fibroblasts during development and ageing. Mech Ageing Dev 102:15-23

26. Kiernan JA 1977 A study of chemically induced acute inflammation in the skin of the rat. Q J Exp Physiol Cogn Med Sci 62:151-161 